SAINTIFIK, Vol.5, No.1, Januari 2019, pp. 8 13

ISSN 2407-4098 (print),

ISSN 2622-8904 (online)

\title{
Keterampilan Berpikir Kritis Mahasiswa STKIP Yapim Maros Pada Mata Kuliah Evolusi
}

\author{
Jirana ${ }^{1}$, Mohammad Amin ${ }^{2}$, Endang Suarsini ${ }^{3}$, Betty Lukiati ${ }^{4}$ \\ ${ }^{1}$ Program Studi Pendidikan Biologi Pascasarjana Universitas Negeri Malang \\ ${ }^{2,3,4}$ FMIPA Jurusan Biologi Universitas Negeri Malang

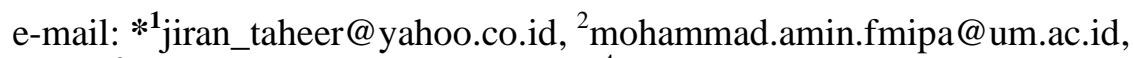 \\ 3endang.suarsini.fmipa@um.ac.id, ${ }^{4}$ betty.lukiati.fmipa@um.ac.id
}

\begin{abstract}
Abstrak
Mata kuliah evolusi merupakan salah satu mata kuliah yang dianggap sulit oleh mahasiswa, sulitnya pemahaman mahasiswa terhadap konsep evolusi disebabkan oleh beberapa masalah sehingga perlu dilakukan beberapa observasi terhadap komponen-komponen dalam proses pembelajaran Evolusi. Penelitian ini bertujuan untuk menganalisis Keterampilan Berpikir mahasiswa terhadap Mata Kuliah Evolusi di Universitas Sulawesi Barat Penelitian ini menggunakan metode survey dengan cara penyebaran angket dan pemberian tes untuk mengetahui pengetahuan mahasiswa tentang konsep evolusi. Berdasarkan survey yang dilakukan terhadap mahasiswa STKIP Yapim Maros Program Pendidikan Biologi dengan 36 orang responden menunjukkan bahwa Keterampilan Berpikir Kritis Mahasiswa STKIP Yapim Maros. Berdasarkan hasil analisis yang didapatkan, maka dapat disimpulkan bahwa keterampilan berpikir mahasiswa biologi STKIP Yapim Maros terhadap mata kuliah Evolusi masih rendah. Oleh karena itu perlu dilakukanpembenahan dalam penelitian lanjutan.
\end{abstract}

Kata kunci: Berpikir Kritis, Evolusi, Pembelajaran

\section{PENDAHULUAN}

Peradaban 21 menuntut output yang yang mempunyai keterampilan berpikir kritis, keterampilan berkomunikasi, keterampilan berkolaborasi, dan kreatif. Program Prioritas penjaminan mutu menyatakan perlunya kesiapan peserta didik dalam menghadapi tantangan Abad 21 (Sardjoko, 2016). Konten pengetahuan dan keterampilan Abad 21 meliputi: (1) thinking; (2) acting; dan (3) living in the world (Greenstein, (2012). Nasional Research Council (2012) menyatakan bahwa individu perlu memiliki kompetensi, salah satunya keterampilan berpikir kritis. Pada abad ini dibutuhkan pembelajaran yang berdasar padareal life (Habok and Nagy, 2016). Pesatnya kemajuan ilmu pengetahuan dan teknologi menuntut penguasaan teknologi informasi dan ilmu pengetahuan. Menghadapi kemajuan teknologi diperlukan kemampuan memperoleh, memilih, dan mengolah informasi yang membutuhkan pemikiran yang kritis, sistematis, logis, dan kreatif.

Terdapat beberapa keterampilan belajar perlu diberdayakan dalam pendidikan abad ke21, salah satunya adalah keterampilan berpikir kritis, yang termasuk sebagai high-order keterampilan pemikiran (Ikuonobe, 2001). Bersama dengan kemajuan ilmu pengetahuan dan teknologi yang mengubah struktur dan pemikiran masyarakat (Gumus et al, 2013). Keterampilan berpikir kritis adalah kemampuan yang dianggap handal yang memainkan peran penting dalam semua aspek kehidupan manusia (Abed et al, 2015). Keterampilan berpikir kritis yang diperlukan harus terus diterapkan dalam proses pembelajaran (Kealey et al, 2005). 
Keterampilan ini perlu ditanamkan dalam setiap peserta didik untuk menanggapi tantangan yang sangat kompleks (Halpern, 2003).

Berpikir kritis merupakan proses menganalisis dan mensintesis suatu argumen, informasi, dan pertanyaan melalui melalui penyelesaian, menyimpulkan, dan mengevaluasi masalah (Suryobroto, 2010; Geng, 2014; Angelo, 1995). Berpikir kritis terdiri atas berbagai komponen yang mempunyai nilai keterampilan berpikir kritis berupa kekuatan mental yang harusnya dimiliki oleh seseorang (Zubaidah, 2015; Browne dan Keeley (2012). Keterampilan berpikir kritis terdiri dari 5 indikator penilaian meliputi memberikan penjelasan sederhana, membangun keterampilan dasar, menyimpulkan, penjelasan lanjut, dan mengatur strategi dan taktik.

Semua orang bisa berpikir, tapi tidak semua orang berpikir secara mendalam. Seseorang cenderung memikirkan banyak hal sehingga tidak fokus. Hal ini sejalan dengan apa yang disampaikan oleh Ennis (1991) bahwa berpikir kritis merupakan berpikir reflektif yang masuk akal yang difokuskan dan memutuskan pada apa yang harus dipercaya atau lakukan.”. Elder dan Paul (2007) menyatakan bahwa "berpikir kritis adalah seni menganalisis dan mengevaluasi pemikiran. Berpikir kritis dianggap seni dan dipraktekkan dengan cara menganalisis dan mengevaluasi cara yang berpikir itu sendiri sehingga kita bisa meningkatkan cara berpikir kita (Ismoyo, 2012).

\section{METODE PENELITIAN}

Penelitian ini dilakukan dengan metode survei. Penelitian ini dilakukan STKIP Yapim Maros. Sampel dari penelitian ini terdiri dari 36 orang mahasiswa yang belum memprogram mata kuliah Evolusi. Pengambilan sampel dilakukan secara purpose sampling. Teknik pengumpulan data yaitu dengan melakukan penyebaran angket terhadap responden. Angket terdiri dari 50 pernyataan mengenai keterampilan berpikir kritis bentuk skala likert. Analisis data dengan menggunakan rumus berikut:

Nilai $=\frac{\text { SkorPerolehan }}{\text { Jml item } \times 5} \times 100$

\section{HASIL DAN PEMBAHASAN}

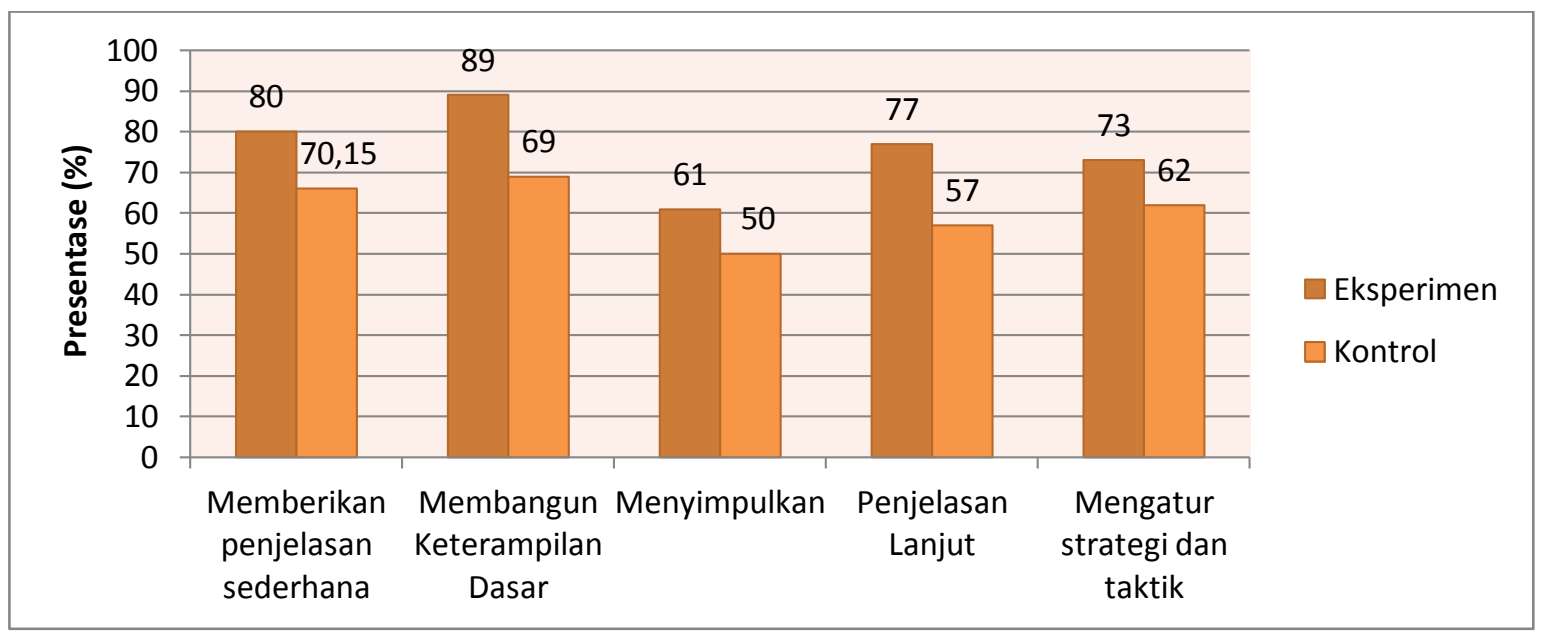

Gambar 1 Hasil Perolehan data angket Keterampilan Berpikir Kritis Mahasiswa setelah proses pembelajaran 
Gambar 1 menunjukkan bahwa indikator membangun keterampilan dasar pada kelas eksperimen memiliki persentase tertinggi sebanyak $89 \%$ dan persentase terendah pada indikator 3 (menyimpulkan) dengan persentase 50\% pada kelas control.

Hasil analisis penyebaran angket ini memiliki nilai ketimpangan antara responden, dalam hasil analisis ini, terdapat beberapa responden yang memiliki nilai terlalu tinggi dan ada juga yang sangat rendah, hal ini disebakan oleh keseriusan responden dalam mengisi angket, terdapat beberapa responden yang mengisi angket dengan kurang teliti. Inti temuan pada penyebaran angket tentang berpikir ktitis ini adalah bahwa keterampilan berpikir kritis mahasiswa pada mata kuliah evolusi masih rendah.

Rendahnya keterampilan berpikir kritis mahasiswa meruapakan suatu hal yang memerlukan perhatian khususnya dari para pemeran pendidikan. Hal ini sejalan yang dikatakan oleh Nasution, 2008 bahwa kemampuan berpikir adalah sarana untuk mencapai tujuan pendidikan agar peserta didik mampu memecahkan masalah taraf tingkat tinggi. Berpikir kritis mempunyai makna yaitu kekuatan berpikir yang harus dibangun pada mahasiswa sehingga menjadi suatu watak atau kepribadian yang terpatri di dalam kehidupan mahasiswa untuk memecahkan segala persoalan hidupnya. Keterampilan berpikir kritis merupakan hal penting bagi mahasiswa karena dengan keterampilan ini mahasiswa mampu bersikap rasional dan memilih alternatif pilihan yang terbaik bagi dirinya. Mahasiswa yang memiliki keterampilan berpikir kritis akan selalu bertanya pada diri sendiri dalam setiap menghadapi segala persoalannya untuk menentukan yang terbaik bagi dirinya. Pemberdayaan keterampilan berpikir kritis pada mahasiswa perlu didahulukan untuk dilakukan yang dapat diintegrasikan melalui metode-metode pembelajaran yang dapat terbukti mampu memberdayakan keterampilan berpikir kritis mahasiswa.

Kedua hasil dapat dilihat bahwa penggunaan model pembelajaran PjBL (Kelas eksperimen) memberikan pengaruh lebih baik dari pada tanpa menggunakan model pembelajaran PjBL (kelas kontrol). Beberapa faktor yang menyebabkan adanya perbedaan kemampuan berpikir kritis pada kelas eksperimen dan kelas kontrol adalah bahwa pada kelas eksperimen mahasiswa dituntut untuk berpikir lebih dalam menyelesaikan tugas-tugas yang diberikan oleh Dosen. Mahasiswa dituntut membuat banyak tugas yang harus diselesaikan dalam jangka waktu tertentu berdasarkan tahapan model pembelajaran PjBL. Berdasarkan pendapat beberapa mahasiswa yang diketahui melalui wawancara, mahasiswa merasa senang dan termotivasi dalam menyelesaikan tugas karena diberikan kebebasan dalam proses penyelesaian tugas, dapat dilakukan di dalam dan di luar kelas.Kebebasan tersebutmembuat mahasiswa lebih bersemangat karena tidak ada tekanan. Pada penyelesaian tugas proyek, mahasiswa bekerja secara berkelompok. Dosen berlaku sebagai fasilitator dan motivator.

Perbedaan nilai yang lain disebabkan karena kelas eksperimen lebif reflektif, produktif, fokus, dan sistematis dalam menyelesaikan tugas, hal ini sesuai dengan teori yang dikemukakan Santrock (2010); Greenstain (2012); Johnson (2009); Ennis (2001); Facione (2013) bahwa berpikir kritis merupakan kemampuan bernalar yang reflektif dan produktif dalam menemukan sebuah jawaban untuk keyakinan diri sehingga dapat menyelesaikan masalah secara sistematis dan berfokus pada kegiatan yang dilakukan. Keterampilan berpikir kritis dari kedua kelompok tidak jauh berbeda,hal ini sama dengan penelitian yang dilakukan oleh Masek dan Yamin (2011) bahwa dalam hal keterampilan berpikir kritis, kemampuan yang dimiliki oleh kedua kelompok tidak jauh berbeda. Hal ini disebabkan dengan adanya berbagai sumber atau referensi yang dapat dijadikan pedoman untuk mendapatkan 
pengetahuan, perbedaan kerja pada kedua kelompok terletak pada model pembelajaran yang digunakan. Pada kelas kontrol mahasiswa juga dituntut untuk menyelesaikan tugas tetapi siswa dibimbing dan di bawah pengawasan Dosen. Pembelajaran dilakukan dalam kelas dengan metode diskusi. Mahasiswa dan Dosen menjawab pertanyaan yang diajukan oleh mahasiswa ataupun Dosen sendiri yang menstimulasi mahasiswa dengan pertanyaanpertanyaan yang mengacu pada materi tertentu, mahasiswa juga berpedoman padabuku yang dipersiapkan oleh Dosen sehingga mahasiswa kurang maksimal untuk berfikir secara mandiri. Mahasiswa cenderung pasif dalam pembelajaran sehingga kemampuan berpikir kritis mahasiswa kurang.

Seorang pemikir yang baik dapat membaca suatu masalah dan memutuskan bagaimana memulai, sedangkan seseorang yang tidak dapat berpikir dengan baik akan sulit membaca masalah terlebih menemukan cara untuk menyelesaikan masalah. Seseorang yang dapat berpikir secara kritis akan menggunakan pengalaman, pengetahuan dalam mengatasi masalah dan menghasilkan karya berdasarkan hasil pemikiran. Kemampuan berpikir kritis seseorang menghasilkan kerja secara sistematis dan percaya diri dalam melakukan sebuah proses. Demikian juga sebaliknya bahwa seseorang yang tidak berpikir secara kritis mempunyai kekurangan atau ketidakmampuan pengetahuan, bekerja kurang sistematis sehingga apa yang dihasilkan seringkali tidak memuaskan, cenderung dapat mengatasi kesulitan,tidak produktif, dan kurang kreatif memunculkan ide. Penelitian ini sesuai dengan penelitian yang dilakukan oleh Chiang \& Lee (2016) bahwa pembelajaran berbasis proyek tidak hanya meningkatkan motivasi belajar siswa sekolah, namun juga memudahkan kemampuan pemecahan masalah siswa. Berpikir kreatif melibatkan rasa ingin tahu sehingga pembelajaran berbasis contextual teaching learning (CTL) yang menjadi salah satu ciri model pembelajaran PjBL dianggap cocok untuk meningkatkan kreativitas mahasiswa. Sistem pengajaran CTLmenawarkan banyak kesempatan bagi mahasiswa untuk menjadikan berpikir kreatif menjadi suatu kebiasaan (Johnson, 2007).

Jika melihat hasil data respon mahasiswa, mahasiwa kelas eksperimen merasa bahwa diri mereka mempunyai kemampuan lebih dalam hal berpikir kritis dibandingkan dengan kelas kontrol. Hal ini dilihat pada gambar 3 bahwa persentase setiap indikator berpikir kritis, persentase respon kelas eksperimen lebih tinggi jika dibandingkan dengan kelas kontrol. Hal ini menandakan bahwa model pembelajaran PjBL yang digunakan dapat meningkatkan dan menstimulasi keberanian mahasiswa dalam mengungkapkan apa yang mereka ketahui, membuat mahasiswa lebih kritis, lebih sistematis dan terarah dalam memahami setiap langkah pembelajaran. Jika dilihat secara detail, hasil analisis penyebaran angket ini memiliki nilai ketimpangan antara responden, Beberapa responden memiliki nilai terlalu tinggi dan ada juga yang sangat rendah, hal ini disebakan oleh beberapa faktor misalnya ketidakseriusan dan ketidaktelitian responden dalam mengisi angket.

Inti temuan pada penyebaran angket tentang berpikir ktitis ini adalah bahwa keterampilan berpikir kritis mahasiswa pada mata kuliah evolusi masih masih perlu pembenahan terutama mengenai model belajar yang digunakan. Rendahnya keterampilan berpikir kritis mahasiswa merupakan suatu hal yang memerlukan perhatian khususnya daripada pemeran pendidikan. Hal ini sejalan dengan teori Nasution (2008) bahwakemampuan berpikir adalah sarana untuk mencapai tujuan pendidikan agar peserta didik mampu memecahkan masalah taraf tingkat tinggi. Berpikir kritis bermakna kekuatan berpikir yang harus dibangun pada mahasiswa sehingga menjadi suatu watak atau kepribadian yang terpatri di dalam 
kehidupan mahasiswa untuk memecahkan segala persoalan hidupnya. Kemampuan berpikir kritis dapat digunakan mahasiswa dalam mencermati pendapat yang berbeda sebagai dasar dan mengarahkan dalam mengambil keputusan (Zubaidah $d k k$, 2015; Johnson, 2009). Pemberdayaan keterampilan berpikir kritis pada mahasiswa perlu didahulukan untuk dilakukan yang dapat diintegrasikan melalui metode-metode pembelajaran yang dapat terbukti mampu memberdayakan keterampilan berpikir kritis mahasiswa.

Pada awal pembelajaran, mahasiswa kesulitan dalam menentukan proyek-proyek yang akan mereka buat, namun dengan berpedoman pada buku dan LKM yang mencantumkan prosedur pelaksanaan proyek, mahasiswa mulai dapat memahami tentang apa yang akan mereka kerjakan. Salah satu kelemahan mahasiswa dalam pembelajaran adalah ketika mereka tidak memahami arah pembelajaran, sehingga mereka menjadi bingung dalam melakukan perintah dosen. Mahasiswa akan kesulitan dalam proses pembelajaran ketika mereka tidak memiliki pedoman belajar. Pemikiran kreatif dibutuhkan dalam memecahkan masalah (Munandar, 1999). Menurut mahasiswa, hal yang paling sulit adalah ketika mereka diminta membuat suatu produk pembelajaran yang sifatnya baru (belum pernah diciptakan oleh seseorang sebelumnya). Setelah melalui beberapa kali pertemuan, mahasiswa pun menjadi terbiasa dengan tugas mereka. Hasil penerapan model pembelajaran PjBL membuat mahasiswa semakin termotivasi untuk berkreasi sehingga mereka membutuhkan pemikiran yang lebih kritis. Penilaian kreativitas dalam proses pembelajaran berfungsi mendiagnosis kekuatan dan kelemahan serta memonitor mahasiswa (Popham, 1995). Respon positif yang ditunjukkan oleh mahasiswa adalah bahwa dengan penerapan model pembelajaran $\mathrm{PjBL}$, mereka dapat melakukan kreasi berdasarkan pengetahuan dan pengalaman mereka masing-masing serta dapat bekerja secara kolaboratif sehingga lebih luwes dalam belajar. Dosen sebagai fasilitator dan motivator tetap melakukan pembimbingan dan pengawasan pada proses belajar mahasiswa agar hasil belajar yang dihasilkan sesuai dengan tujuan belajar.

\section{KESIMPULAN}

Berdasarkan hasil analisis yang didapatkan, dapat disimpulkan bahwa keterampilan berpikir mahasiswa biologi STKIP Yapim Maros terhadap mata kuliah Evolusi masih rendah. Penilaian keterampilan berpikir kritis mahasiswa berada pada kategori sedang, terdapat beberapa mahasiswa yang mempunyai nilai tinggi.

\section{DAFTAR PUSTAKA}

Angelo. 1995. Beginning The Dialogue: Thoughts on Promoting Critical Thinking: Classroom Assesment for Critical Thinking. Teaching of Psychology, 22 (1):6-7.

Browne \& Keeley. 2012. Pemikiran Kritis. Jakarta: Indeks

Ennis, R.H. 1985. Goal for a Critical Thinking Curiculum, Developing Minds: a Resource Book for Teaching Thinking. Virginia. ASDC.

Facione. 2013. Critical Thinking: What it is and Why it Counts. Insight Assesmen. Update, 128.

Geng. 2014. An Content Analysis of the Definition of Critical Thinking. Asian Social. Science, 10(19): 82-95.

Greenstein, L. 2012. Assessing 21st Century Skills a Guide to Evaluating Mastery and Authentic Learning. India: Sage Publication Asia Pasific Pte. Ltd 
Habok \& Nagy. 2016. Inservice teachers' perceptionsof projectbased learning. SpringerPlus.

Johnson, E.B. 2002. Contextual Teaching and Learning: What It is and Why It's Here to Stay. Thousand Oaks, California: Corwin Press, Inc.

Johnson. 2007. Contextual Teaching and Learning, Menjadikan Kegiatan Belajar Mengajar Mengasyikkan dan Bermakna. Bandung: Mizan Learning Center (MLC).

Johnson. 2009. Contextual Teaching and Learning, Menjadikan Kegiatan Belajar Mengajar Mengasyikkan dan Bermakna. Bandung: Kaifa.

Marhaeni \& Budi Adnyana. 2007. Asesmen Berbasis Kelas. Materi PLPG. Undiksha.

Masek, A \& Yamin, S. 2012. The Impact of Instructional Methods on Critical Thinking:AComparisonofProblem-BasedLearningandConventional Approach inEngineering Education. International Scholarly Research Network ISRN Education. 1-6.

Munandar, U. 1999. Mengembangkan Bakat dan Kreativitas Anak Sekolah. Jakarta: Grasindo.

National Research Council (NRC). 2011. Assessing 21st Century Skills: Summary of a Workshop. J.A. Koenig, Rapporteur. Committee on the Assessment of 21st Century Skills.Board on Testing and Assessment, Division of Behavioral and Social Sciences and Education. Washington, DC: The National Academies Press.

Popham, W. J. 1995. Classroom Assessment. What Teachers Need to Know. Needham Heights: Allyn \& Bacon.

Ruggiero, V.R. 1998. The Art of Thinking: A Guide to Critical and Creative Thought. New York: Long-man, an Imprint of Addison Wesley Longman, Inc.

Santrock, W. J. 2010. Psikologi Pendidikan. Jakarta: Kencana.

Sardjoko, S. 2016. Multilateral Meeting dalam rangka Penyusunan RKP 2017 Pembangunan Pendidikan Nasional: Pembangunan Manusia, Masyarakat, dan Kebudayaan BAPPENAS. Jakarta.

Suarni, K. 1996. Perkembangan dan Belajar Anak. Singaraja: STKIP.

Suryobroto. 2010. Proses Belajar Mengajar di Sekolah. Jakarta: Rineke Cipta. 